\title{
Another Novel Subgenotype of Hepatitis B Virus Genotype C From Papuans of Highland Origin
}

\author{
Juniastuti, ${ }^{1,2}$ Takako Utsumi, ${ }^{2,3}$ Victor Eka Nugrahaputra, ${ }^{4}$ Mochamad Amin, ${ }^{2}$ \\ Soetjipto, ${ }^{2,5}$ Yoshitake Hayashi, ${ }^{3}$ Hak Hotta, ${ }^{3}$ and Maria Inge Lusida ${ }^{1,2 *}$ \\ ${ }^{1}$ Department of Microbiology, School of Medicine, Airlangga University, Surabaya, Indonesia \\ ${ }^{2}$ Indonesia-Japan Collaborative Research Center for Emerging and Re-emerging Infectious Diseases, Institute of \\ Tropical Disease, Airlangga University, Surabaya, Indonesia \\ ${ }^{3}$ Center for Infectious Diseases, Kobe University Graduate School of Medicine, Kobe, Japan \\ ${ }^{4}$ Department of Microbiology, School of Medicine, Cendrawasih University, Jayapura, Indonesia \\ ${ }^{5}$ Department of Biochemistry, School of Medicine, Airlangga University, Surabaya, Indonesia
}

Hepatitis B virus (HBV) genotypes and subtypes have been identified worldwide. As HBV genotypes/subtypes, the HBV subgenotypes seem to be associated with their geographical distribution and ethnic origin. A previous study showed the novel HBV subgenotype 66 based on the complete genome sequences of isolates in Papua, Indonesia. In the present study, further characterization of HBV in Jayapura (capital of Papua Province), particularly from native people of Papua originating from the highland (highland Papuans) and those from the lowland (lowland Papuans) were examined. Of $32 \mathrm{HBV}$ isolates from both highland and lowland Papuan blood donors with HBsAg positive, part of the $\mathrm{S}$ gene and the core gene sequences were analyzed. Analyses of some isolates from highland Papuans were confirmed by the complete genome sequences. Most HBV isolates were classified into genotype C (78.1\%), followed by genotype B $(18.8 \%)$, and genotype D (3.1\%). The subtype $a d r$ was predominant $(71.9 \%)$, followed by adw2 $(25.1 \%)$, and ayw2 (3.1\%). As with previous findings, phylogenetic analyses revealed that most HBV isolates from Papuans, C/adr, belonged to subgenotype $\mathrm{C}$. Interestingly, some $\mathrm{C} / \mathrm{adr}$ isolates from highland Papuans formed a distinct cluster from all reported subgenotypes of $\mathrm{HBV} / \mathrm{C}$, and they differed from HBV/C1-C10 by $4.2-7.2 \%$ over the complete genome. SimPlot analysis showed no evidence of recombination with $\mathrm{HBV} / \mathrm{C} 1-\mathrm{C} 10$. The isolated life and closed social systems of highland Papuans, even though some have been moving to Jayapura, likely contribute to the formation of this unique cluster of infection with a novel subgenotype of HBV, named C11. J. Med. Virol. 83:225-234, 2011. @ 2010 Wiley-Liss, Inc.
KEY WORDS: hepatitis B virus; genotypes; novel subgenotypes; subtypes

\section{INTRODUCTION}

Hepatitis B virus (HBV) infection is a serious global health problem. Indonesia belonged to the moderate-tohigh hepatitis B endemic region [Khan et al., 2004]. Carrier rates among blood donors ranged from $2.1 \%$ to 9.5\% in 11 large cities and even up to $10.5 \%$ in Jayapura, Papua Province [Sastrosoewignjo et al., 1991; Khan et al., 2004].

Ten genotypes (from A to J) of HBV have been identified worldwide, based on a divergence of $8 \%$ or more of the complete genome, and more than $4 \%$ at the level of the S gene [Okamoto et al., 1988; Norder et al., 1994; Magnius and Norder, 1995; Hannoun et al., 2000; Stuyver et al., 2000; Arauz-Ruiz et al., 2002; Kramvis et al., 2005; Olinger et al., 2008; Tatematsu et al., 2009]. Nine HBV subtypes ( $a d w 2, a d w 4, a d r q-, a d r q+, a y w 1$ 4$, ayr $)$ were defined by two mutually exclusive determinant pairs, $d / y$ and $w(w 1-4) / r$, and a common determinant ' $a$ ' of HBsAg [Magnius and Norder, 1995; Kramvis et al., 2005]. HBV isolates of different geno-

Grant sponsor: Joint Grant of Eijkman Institute for Molecular Biology; Grant sponsor: Committee of Research and Development (Department of Health, Indonesia); Grant sponsor: Program of Founding Research Centers for Emerging and Reemerging Infectious Diseases; Grant sponsor: Ministry of Education, Culture, Sports, Science and Technology (MEXT), Japan.

*Correspondence to: Maria Inge Lusida, Institute of Tropical Disease, Airlangga University, Campus C Mulyorejo, Surabaya 60115, Indonesia. E-mail: ingelusida@yahoo.com

Accepted 25 August 2010

DOI 10.1002/jmv.21963

Published online in Wiley Online Library

(wileyonlinelibrary.com). 
types and subtypes show different geographical distribution, virological characteristics, and possibly, clinical outcomes [Kao et al., 2000; Orito et al., 2001; Kao, 2002; Kidd-Ljunggren et al., 2002]. They could also provide historical information on the migration pattern of the ancestors of the local population [Magnius and Norder, 1995; Orito et al., 2001].

Subgenotypes have been identified for certain HBV genotypes. $\mathrm{HBV} / \mathrm{C}$ has been classified into ten subgenotypes (C1-C10) [Sugauchi et al., 2001; Huy et al., 2004; Chan et al., 2005; Sakamoto et al., 2006; Lusida et al., 2008; Mulyanto et al., 2009, 2010], HBV/D into six subgenotypes (D1-D6) [Norder et al., 2004; Bozdayi et al., 2005; Banerjee et al., 2006; Schaefer, 2007; Lusida et al., 2008], and HBV/B into eight subgenotypes (B1B8) [Sugauchi et al., 2001; Nagasaki et al., 2006; Sakamoto et al., 2006; Sakamoto et al., 2007; Nuraeny et al., 2008; Mulyanto et al., 2009]. As HBV genotypes/ subtypes, the HBV subgenotypes seem to be associated with their geographical distribution and ethnic origin.

Previous studies of genotype-subtype distribution of $\mathrm{HBV}$ in Jayapura, Papua, reported that $\mathrm{C} / a d r$ was the most predominant [Sastrosoewignjo et al., 1991; Mulyanto et al., 1997]. It was speculated that the ancestors of $\mathrm{HBV} / a d r$-infected inhabitants of the eastern-most part of Indonesia, like Papua, came most likely from Melanesia where $a d r$ is largely found [Mulyanto et al., 1997]. Norder et al. [1994] found that C/adr isolates in Melanesia and Polynesia (HBV/C3) had no $q$ determinant, differed from $\mathrm{C} / a d r$ isolates in Far East Asia (HBV/C2) [Kramvis et al., 2005] and in South East Asia (HBV/C1) [Huy et al., 2004] which had the $q$ determinant. Recently, based on part of the $\mathrm{S}$ gene and the core gene, Lusida et al. [2008] reported that most $\mathrm{C} / a d r$ isolates of $\mathrm{HBV}$ from Papua had no $q$ determinant (A159/A177), but they belonged to a novel subgenotype (HBV/C6). This finding was confirmed by Utsumi et al. [2009] based on the complete HBV genome.

The aim of this study was to characterize further HBV isolates from Papua, particularly from its native highland and lowland Papuans.

\section{MATERIALS AND METHODS \\ Collection of Field Samples}

Serum samples were taken from both highland and lowland Papuan blood donors, who visited the Blood Transfusion Unit-Indonesian Red Cross in Jayapura, Papua Province, from July 2006 to September 2006, and were screened for HBsAg using the immunochromatography method (entebe HBsAg strip, Hepatika Laboratory, Mataram, Indonesia). Thirty-two (4.63\%) of the 691 sera tested positive for HBsAg were subsequently analyzed. The descent of each Papuan carrier was carefully documented for three previous generations, both maternally and paternally. All sera were stored at $-20^{\circ} \mathrm{C}$ until transported to the Institute of Tropical Disease in Surabaya, where they were stored at $-80^{\circ} \mathrm{C}$. Ethical clearance of this study was obtained from the ethics committee of the School of Medicine, Airlangga
University in Surabaya, Indonesia. Informed consent for participation in this study was obtained from each individual.

\section{Viral DNA Extraction, PCR Amplification, and Sequencing}

HBV DNA was extracted from $100 \mu \mathrm{l}$ serum samples using DNAzol reagent (Invitrogen, Carlsbad, CA). The extracted DNA was used as a template for the amplification of the respective gene regions. PCRs were performed with the PCR master mix (Fermentas, Foster City, CA). The reactions contained $25 \mu$ l PCR master mix, $10 \mu \mathrm{l}$ DNA, and $0.5 \mu \mathrm{l}$ of each primer with a concentration of $20 \mathrm{pmol} / \mu \mathrm{l}$, in a total reaction volume of $50 \mu \mathrm{l}$. The thermocycling condition included a 5 -min denaturation step of $94^{\circ} \mathrm{C}$, followed by 40 cycles of $1 \mathrm{~min}$ at $94^{\circ} \mathrm{C}, 1 \mathrm{~min}$ at $55^{\circ} \mathrm{C}$, and $2 \mathrm{~min}$ at $72^{\circ} \mathrm{C}$.

Part of the $\mathrm{S}$ gene was amplified in the first round using primers P7 (5'-GTG GTG GAC TTC TCT CAA TTT TC-3', nt 256-278) and P8 (5'-CGG TAW ${ }^{[\mathrm{A} / \mathrm{T}]}$ AAA GGG ACT CAM ${ }^{[\mathrm{A} / \mathrm{C}]}$ GAT-3', nt 796-776). If the first round PCR was negative, the second round PCR was performed using primers HBs1 (5'-CAA GGT ATG TTG CCC GTT TG-3', nt 455-474) and HBs2 (5'-AAA GCC CTG CGA ACC ACT GA-3', nt 713-694). Part of the core gene was amplified using primers HBc1 (5'-TTA CAT AAG AGG ACT CTT GG-3', nt 1650-1669) and HBc2 (5'TAA AGC CCA GTA AAG TTT CC-3', nt 2494-2475) [Lusida et al., 2008]. For confirmation of analyses of part of the $\mathrm{S}$ gene and the core gene of some isolates, the amplification of the complete HBV genome was determined by the method reported previously [Sugauchi et al., 2001].

Nucleotide sequences of the amplified fragments were determined using the BigDye Deoxy Terminator cycle sequencing kit with an ABI Prism 310 Genetic Analyzer (Applied Biosystems, Foster City, CA).

\section{Analyses of Sequences}

HBV genotypes were determined based on the homologous percentage of $>96 \%$ in the S gene compared with $\mathrm{HBV}$ isolates from International DNA databases (DDBJ/EMBL/GenBank) [Magnius and Norder, 1995; Arauz-Ruiz et al., 1997], using the program GenetyxWin version 9.0 (Genetyx Corporation, Tokyo, Japan).

Nucleotide sequences of $\mathrm{HBV}$ were aligned by the program CLUSTAL X version 1.83 and analyzed further as belows. HBV subtypes were deduced on the basis of the predicted amino acid sequence substitutions at positions $122,127,134,159,160,177$ in the $\mathrm{S}$ gene [Okamoto et al., 1988; Norder et al., 1994; Kramvis et al., 2005]. Phylogenetic trees were constructed by the Neighbor-Joining method and bootstrap resampling was performed 1,000 times, using the Molecular Evolutionary Genetic Analysis (MEGA) version 4.1 (http:// www. megasoftware.net). HBV subgenotypes were assigned as described previously [Sugauchi et al., 2001; Huy et al., 2004; Norder et al., 2004; Chan et al., 2005; Kramvis et al., 2005; Banerjee et al., 2006; 
Nagasaki et al., 2006; Sakamoto et al., 2006; Schaefer, 2007].

\section{Examination of Evidence for Recombination}

Possible HBV genetic recombination events were investigated using the bootscan analysis implemented in the SimPlot software program, version 3.5.1 [Robertson et al., 1995; Lole et al., 1999].

\section{Nucleotide Sequence Accession Numbers}

The nucleotide sequence data reported in this study have been assigned DDBJ/EMBL/GenBank accession numbers AB495096-AB495106, AB495108$\mathrm{AB} 495115, \mathrm{AB} 495117-\mathrm{AB} 495122$ for 25 partial $\mathrm{S}$ gene sequences of HBV/C isolates, AB537944-AB537951 for 8 partial core gene sequences of $\mathrm{HBV} / \mathrm{C}$ isolates, and AB560661-AB560662 for two complete genome sequences of $\mathrm{HBV} / \mathrm{C}$ isolates.

\section{RESULTS}

A total of $32 \mathrm{HBsAg}$-positive sera were obtained from native Papuan blood donors (all male; aged $18-52$ years, mean 29.4 years). Twenty-five were lowland Papuans and the rest (21PU, 22PU, 23PU, 43PU, 48PU, 58PU, and $60 \mathrm{PU}$ ) were highland Papuans.

The distribution of HBV genotypes among 32 Papuans indicated that most isolates $(78.1 \%)$ were classified into genotype $\mathrm{C}$, followed by genotype $\mathrm{B}(18.8 \%)$ and $\mathrm{D}(3.1 \%)$ (Table I).

The HBV subtypes were determined by aligning 32 amino acid sequences from Papuans and 43 reported HBV sequences (A-J genotypes) including those of reported Papua sequences, at the amino acids positions $117-180$ of the S gene (Fig. 1). By analyzing amino acid substitutions at positions $122,127,134$, and 160 , it was found that subtype $a d r$ (71.9\%) was predominant, followed by adw2 (25.1\%) and ayw2 (3.1\%) (Table I). Of the $23 a d r$ isolates, 17 isolates (74\%) had alanine (A) at position 159 and valine (V) at position 177 , and this combination was considered important for the expression of the $q$ determinant. The other $a d r$ isolates (26\%) from Papuans had no $q$ determinant (A159/A177), which had different combination from adrq-isolates

TABLE I. HBV Genotypes and Subtypes Among HBsAg-

Positive Sera From Papuan Blood Donors in Jayapura

\begin{tabular}{lcc}
\hline $\begin{array}{l}\text { HBV genotypes/ } \\
\text { subtypes }\end{array}$ & $\begin{array}{c}\text { No. of Papuan } \\
\text { blood donors }(\%)\end{array}$ & Total $(\%)$ \\
\hline $\mathrm{B}$ adw2 & $6(18.8)$ & $6(18.8)$ \\
$\mathrm{C}$ adw2 & $2(6.3)$ & $25(78.1)$ \\
$\begin{array}{c}\text { adrq+ } \\
\text { adrq- }\end{array}$ & $17(53.1)$ & \\
$\mathrm{D}$ ayw2 & $6(18.8)$ & $1(3.1)$ \\
Total & $1(3.1)$ & $32(100)$ \\
\hline
\end{tabular}

in Melanesia and Polynesia (V159/A177) (Fig. 1 and Table I).

All HBV isolates with subtype $a d r$ belonged to genotype $\mathrm{C}$, adw2 to genotype $\mathrm{B}$ or $\mathrm{C}$, and ayw2 to genotype $\mathrm{D}$ (Table I).

Phylogenetic analysis of part of the S gene (nt 503694) of the HBV genome revealed that most $\mathrm{C} / a d r$ isolates (19/23) from Papuans were classified into subgenotype C6. Two C/adr isolates (21PU and 43PU) from highland Papuans and all $\mathrm{C} / a d r$ isolates from lowland Papuans belonged to $\mathrm{C} 6$ of a Papua cluster. However, the other $\mathrm{C} / a d r$ isolates (22PU, 23PU, 58PU, and 60PU) from highland Papuans formed a single cluster, distinct from all reported subgenotypes of HBV/ C, including C6 (Fig. 2). Phylogenetic analysis of part of the core gene (nt 1916-2401) also showed that three isolates from highland Papuans (23PU, 58PU, and 60PU) were classified into a distinct cluster from all subgenotypes C1-C10 (Fig. 3). Consistently, phylogenetic analysis of the complete HBV genome of two isolates from highland Papuans (58PU and 60PU) confirmed these results, with a bootstrap value of $100 \%$ at its bifurcation, indicating that these isolates were classifiable into a new subgenotype (provisionally designated C11) (Fig. 4).

Divergences in the complete genome sequences of the novel subgenotype HBV/C11 were examined by comparing with the reported sequences of previous subgenotypes of $\mathrm{HBV} / \mathrm{C}(\mathrm{C} 1-\mathrm{C} 10)$. The two HBV/C11 isolates (58PU and 60PU) showed 3.0\% divergence from each other. On the other hand, they showed divergences of $5.2-5.7 \%$ with $\mathrm{HBV} / \mathrm{C} 1,4.8-5.1 \%$ with $\mathrm{HBV} / \mathrm{C} 2,4.2-$ $5.1 \%$ with $\mathrm{HBV} / \mathrm{C} 3,6.3-6.6 \%$ with $\mathrm{HBV} / \mathrm{C} 4,6.1-6.4 \%$ with $\mathrm{HBV} / \mathrm{C} 5,4.2-7.2 \%$ with $\mathrm{HBV} / \mathrm{C} 6,5.6-6.1 \%$ with $\mathrm{HBV} / \mathrm{C} 7,4.6-5.1 \%$ with $\mathrm{HBV} / \mathrm{C} 8,4.3-4.9 \%$ with $\mathrm{HBV} /$ C9, and $6.6-6.7 \%$ with HBV/C10.

To investigate possible recombination in the 58PU genome, a bootscan analysis of aligned complete HBV genomes was performed using SimPlot software. Figure 5 shows the bootscanning plots and the genome-wide similarity score for the 58PU isolate (HBV/C11) in comparison with a reference set consisting of reported subgenotypes of HBV/C (Fig. 5). It showed no significant evidence of recombination between $\mathrm{C} 11$ and previous subgenotypes of $\mathrm{HBV} / \mathrm{C}(\mathrm{C} 1-\mathrm{C} 10)$.

\section{DISCUSSION}

Papua, the western part of New Guinea, is a part of Indonesia. The native people of Papua, called Papuans, are divided into more than 271 different tribes, which show a great variety of cultures and languages [Djoht, 2002]. They spread into two major different geographic zones. Papuans who live in central mountainous region/ highland zones are called highland Papuans, and Papuans who live in swampy and malarial coastal regions/lowland zones are called lowland Papuans. Unlike the lowland people, highland Papuans are firmly attached to their traditions and have not responded to government modernization programs [Feil, 1995]. This 

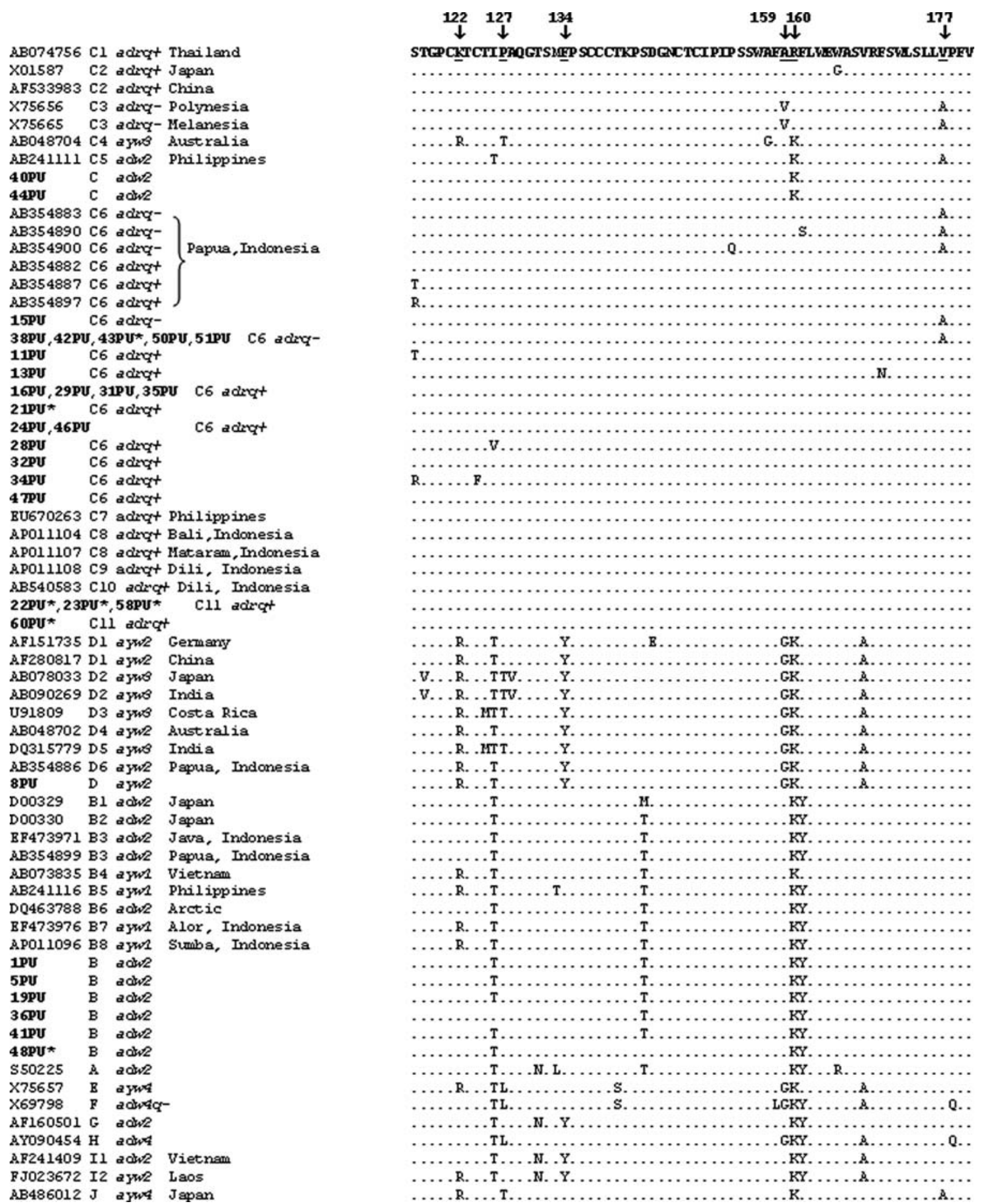

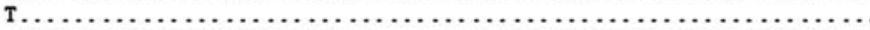

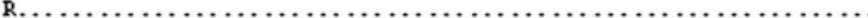

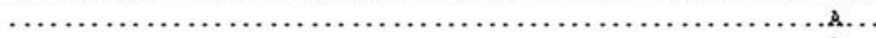

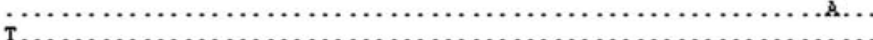

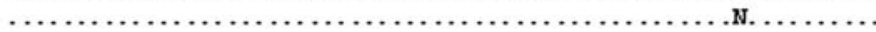

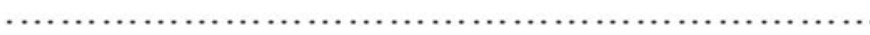

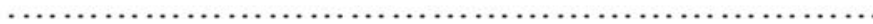

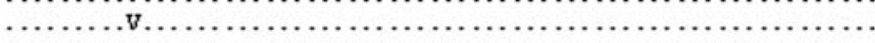
$\mathrm{R}$.

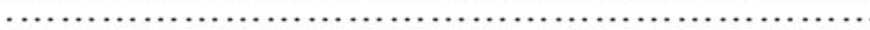

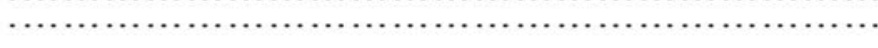

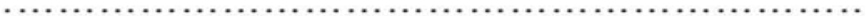

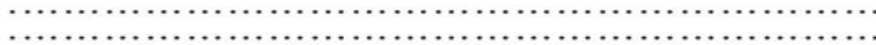

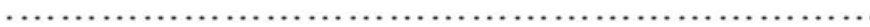

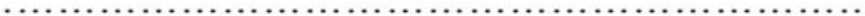

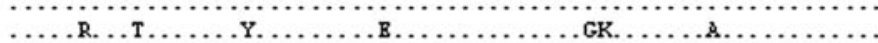

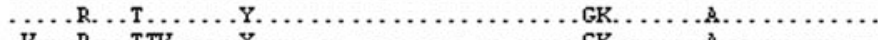

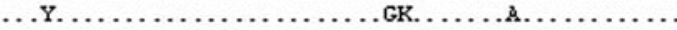

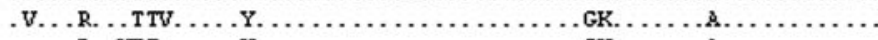

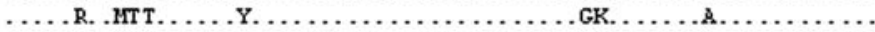

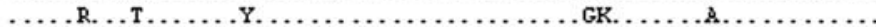

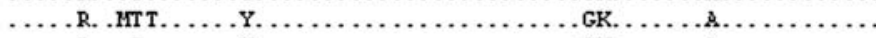

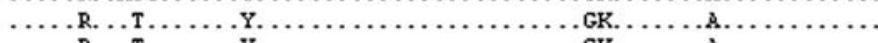

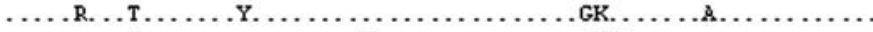

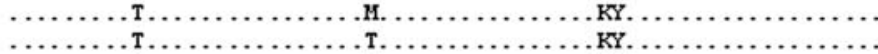

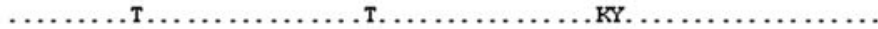

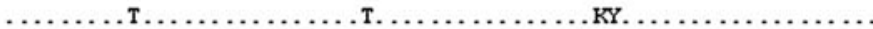
… R. т.

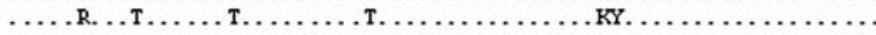

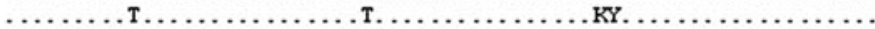

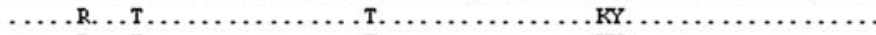

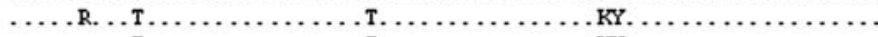

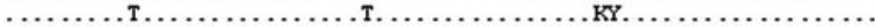

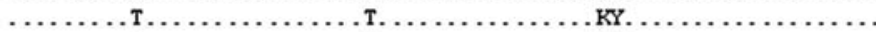
‥

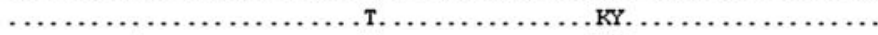

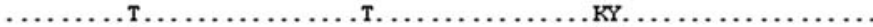

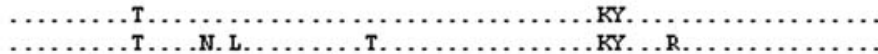

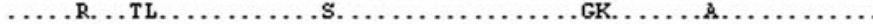

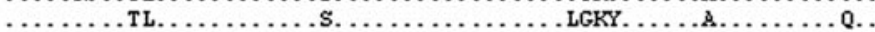
…

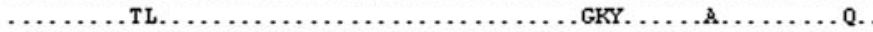

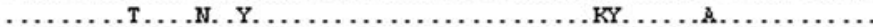
… R. . . . . . . .

Fig. 1. Alignment of amino acid sequences of HBV isolates from 32 Papuans (code: PU, shown in bold), and 43 reported sequences of all HBV genotypes (A-J) and subgenotypes including $C 6$ of a Papua cluster. Reported isolates downloaded from the databases are indicated with the accession numbers, genotypes/ subgenotypes/subtypes and region/country origins. PU samples were obtained from lowland Papuans and $\mathrm{PU}^{*}$ were from highland Papuans. The sequences correspond to amino acids $117-180$ of the $\mathrm{S}$ gene.

study not only yielded the anticipated HBV isolates clustered into $\mathrm{HBV} / \mathrm{C} 6$, but also revealed a novel subgenotype unique to highland Papuans.

This study found that $78.1 \%$ HBV isolates of 32 Papuan blood donors were classified into genotype C, followed by genotype B (18.8\%) and D (3.1\%) (Table I).
No HBV isolates were found with genotypes A, E, F, G, $\mathrm{H}$, I, or J. These results confirmed the previous studies [Sastrosoewignjo et al., 1991; Usuda et al., 1999; Lusida et al., 2008]. Each HBV genotype has a characteristic geographic distribution, even within a single country, as has been observed in China, India, USA, and Indonesia 
$S$ gene

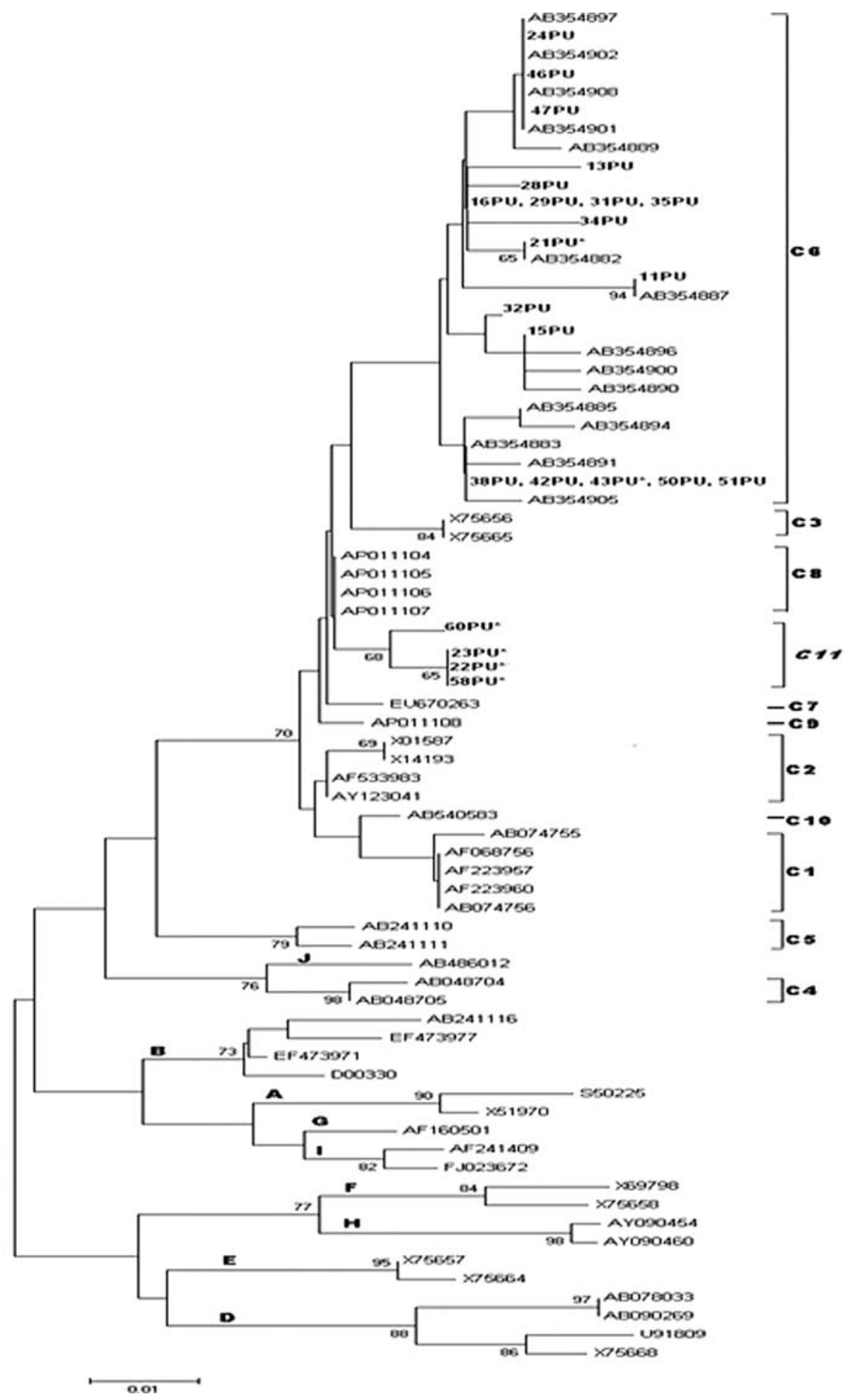

Fig. 2. Neighbor-joining phylogenetic tree of C/adr HBV isolates from 23 Papuans (code: PU, shown in bold) together with all reported HBV genotypes and subgenotypes of $\mathrm{HBV} / \mathrm{C}$, including $\mathrm{C} 6$ of a Papua cluster (indicated with the accession numbers); on the basis of partial S genes (nt 503-694). PU samples were obtained from lowland Papuans and PU* samples were from highland Papuans. The genotypes are indicated on the branches, and the subgenotypes are on the right. Bootstrap values are indicated for each branch.

as well. The genotype distribution can be influenced by the ethnic background and the country origin of the individual carriers of the virus [Kramvis et al., 2005]. Indonesia has hundreds of ethnic groups and languages
[Sofro, 1982]. It is characterized by its national motto"Bhinneka Tunggal Ika" or "unity in diversity." The diversity in this country can now be assessed also in the light of the HBV genotypes. In the western part of 


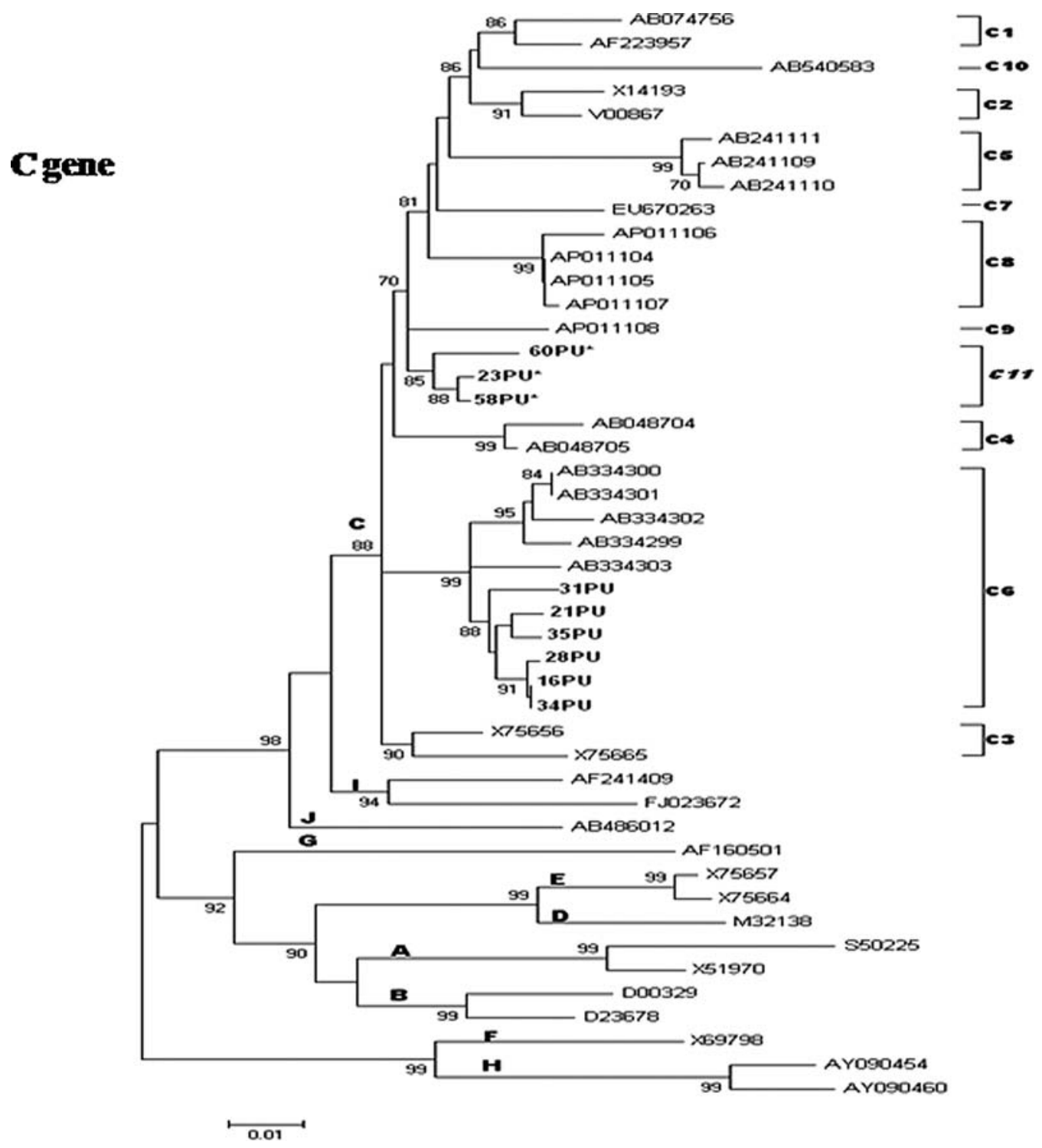

Fig. 3. Neighbor-joining phylogenetic tree of C/adr HBV isolates from nine Papuans (code: $\mathrm{PU}$, shown in bold) together with all reported HBV genotypes and subgenotypes of $\mathrm{HBV} / \mathrm{C}$, including $\mathrm{C} 6$ of a Papua cluster (indicated with the accession numbers); on the basis of part of the core genes (nt 1916-2401). All PU samples were obtained from lowland Papuans and PU* were from highland Papuans. The genotypes are indicated on the branches, and the subgenotypes are on the right. Bootstrap values are indicated for each branch.

Indonesia, the HBV genotype $\mathrm{B}$ is predominant, while the HBV genotype $\mathrm{C}$ is predominant in the eastern part of Indonesia, especially in Papua [Sastrosoewignjo et al., 1991; Mulyanto et al., 1997; Usuda et al., 1999; Lusida et al., 2008]. It should be noted that patients who were infected with HBV genotype $\mathrm{C}$ tend to contract hepatocellular carcinoma and are associated with a higher frequency of core promoter mutation and with a lower response rate to lamivudine and IFN- $\alpha$ therapy than those infected with HBV genotype B [Kao, 2002].

The subtype $a d r(71.9 \%)$ was predominant in HBV isolates from Papuan blood donors, followed by adw2 (25.1\%), and ayw2 (3.1\%) (Table I). These findings confirmed the observation of Mulyanto et al. [1997], that $76.9 \%$ of 13 isolates from adult population of Papuan in Jayapura belonged to subtype $a d r$, and Lusida et al.'s [2008] finding, that $85.2 \%$ of 23 isolates from blood donors in Papua belonged to subtype $a d r$. Again, these data agreed with the HBV subtypedistribution map in eastern part of Indonesia and the fact that Jayapura is within the $a d r$-zone.

All HBV isolates with subtype $a d r$ belonged to genotype $\mathrm{C}, a d w 2$ to genotype $\mathrm{B}$ or $\mathrm{C}$ and ayw2 to genotype $\mathrm{D}$. These were consistent with $\mathrm{HBV}$ genotypes and subtypes relationship. What is more, as reported, subtype $a d r$ can rarely be found in genotype $\mathrm{B}$, subtype adw2 can be found in genotypes A, C, F, G, and subtype ayw2 can be found in genotypes A and C [Kramvis et al., 2005]. 


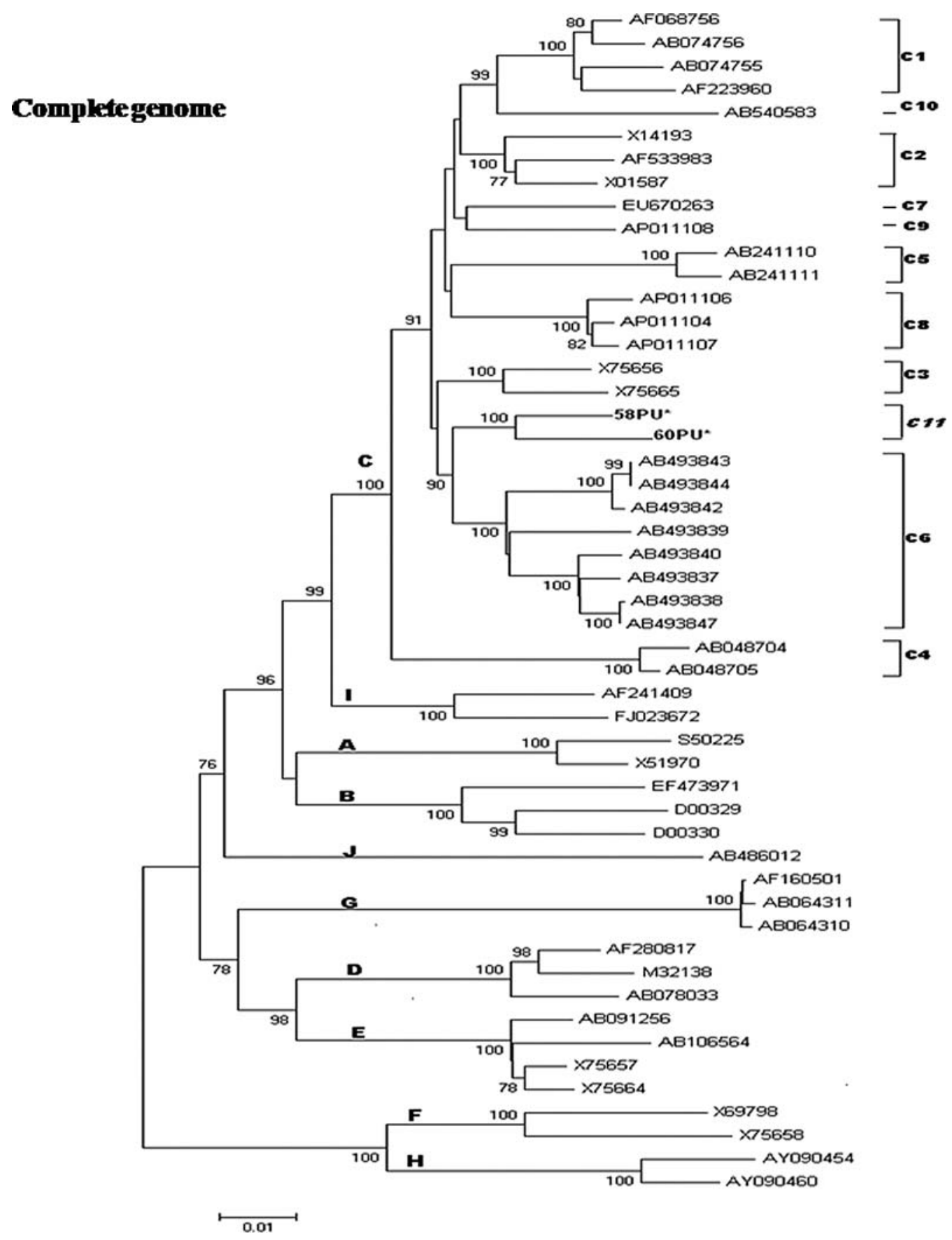

Fig. 4. Neighbor-joining phylogenetic tree of C/adr HBV isolates from two highland Papuans (code: PU*, shown in bold) together with all reported HBV genotypes and all subgenotypes of HBV/C, including C6 of a Papua cluster (indicated with the accession numbers); on the basis of the complete genome. The genotypes are indicated on the branches, and the subgenotypes are on the right. Bootstrap values are indicated for each branch.

HBV isolates from Papuans were dominated by $\mathrm{C} / a d r$ (71.9\%). It was speculated that the ancestors of HBV/ $a d r$-infected inhabitans of that eastern-most part of Indonesia, most likely came from Melanesia where $a d r$ is largely found [Mulyanto et al., 1997]. Nevertheless, based on phylogenetic analyses of part of the $\mathrm{S}$ and core genes, as Lusida et al.'s [2008] finding, it was found that most Papuan isolates $(\mathrm{C} / a d r)$ belonged to subgenotype
HBV/C6 (Indonesia: Papua), distinct from HBV/C1 (Vietnam and Thailand), HBV/C2 (Japan, Korea, and China), HBV/C4 (Australia), HBV/C5 (Philippines), $\mathrm{HBV} / \mathrm{C} 7$ (Philippines), HBV/C8 (Indonesia: Bali, Mataram, Kalimantan), HBV/C9 (Indonesia: Timor), HBV/C10 (Indonesia: Timor) and especially from HBV/C3 (Melanesia and Polynesia) (Fig. 2). This result was consistent with finding of the Indonesian 


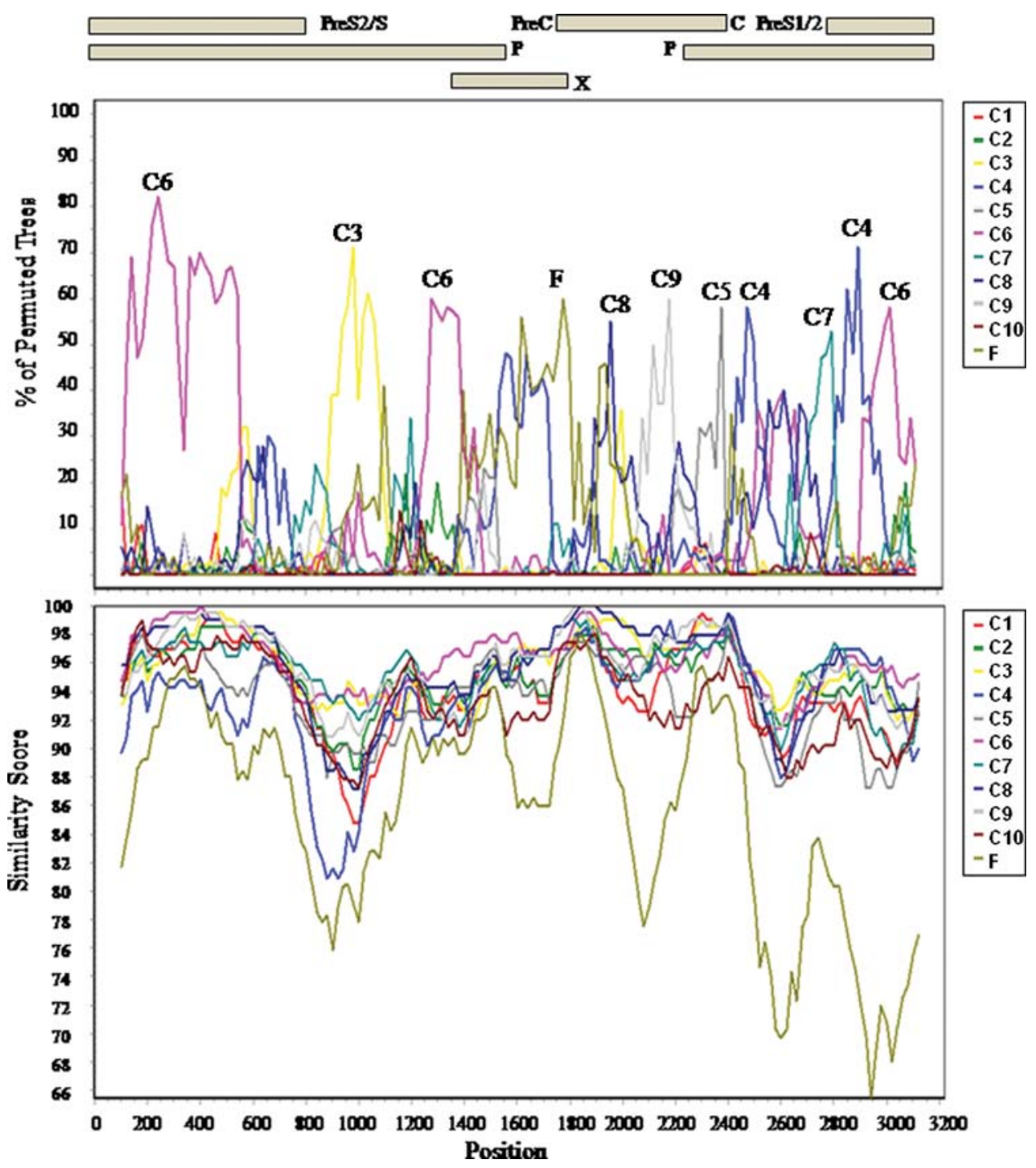

Fig. 5. Complete genome scanning carried out by the SimPlot program for the 58PU* isolate from one highland Papuan versus 25 selected genotype C HBV isolates, grouped by subgenotype and genotype F HBV isolate as an outgroup. Top panel: Bootscanning of HBV sequence. The $y$-axis shows the percentage of permuted trees using a sliding window 200 -bp wide centered on the position plotted, with a step size between plots of $20 \mathrm{bp}$. Bottom panel: The results from SimPlot analysis are shown. The $y$-axis shows the percentage of identity within a sliding window 200 -bp wide centered on the position plotted, with a step size between plots of $20 \mathrm{bp}$.

anthropologists, Koentjaraningrat and Bachtiar, that Papuan languages are not grouped into Melanesian languages. In addition, although most $a d r$ isolates (74\%) from Papuans had the $q$ determinant (Table I), they were not clustered into $\mathrm{HBV} / \mathrm{C} 1$ and $\mathrm{HBV} / \mathrm{C} 2$ which were frequently found with the same subtype, $a d r q+$ [Huy et al., 2004; Kramvis et al., 2005].

Interestingly, based on phylogenetic analysis of part of the $\mathrm{S}$ gene, four $\mathrm{C} / a d r$ isolates (22PU, 23PU, 58PU, and 60PU) from highland Papuans belonged to a distinct cluster from all reported subgenotypes of $\mathrm{HBV} / \mathrm{C}$, including $\mathrm{C} 6$ of a Papua cluster (Fig. 2). This unique cluster was also shown on the basis of part of the core gene (Fig. 3). All these results were confirmed by phylogenetic analysis based on the complete genome sequences, with a significant bootstrap value $(100 \%)$ at its bifurcation (Fig. 4). The finding of the novel subgenotype (provisionally designated C11) was also confirmed on the basis of divergences of the complete genome sequences by 4-8\% with other known subgenotypes of HBV/C (C1-C10). Furthermore, no significant evidence of recombination was found between the 58PU genome (subgenotype C11) and the other 10 subgenotypes of HBV/C (Fig. 5). The isolated life and closed social systems of highland Papuans in the central mountainous region/highland zones likely contribute to this finding.

It was found also that two other $\mathrm{C} / a d r$ isolates (21PU and 43PU) from highland Papuans were grouped together with all $\mathrm{C} / a d r$ isolates from lowland Papuans into C6 cluster, not into C11 cluster (Fig. 2). Some highland Papuans have descended to more open and 
cultivated areas in the lowland zones and adjusted to a new life. This migration is ongoing, and it is possible that there are many horizontal transmissions of HBV from lowland Papuans to highland Papuans.

In conclusion, a novel HBV subgenotype, C11, from highland Papuans, was identified. This study also confirmed that most $\mathrm{HBV} / \mathrm{C}$ isolates in Papua were classified into subgenotype C6. The isolated life of highland Papuans could be the reason for the new finding of subgenotype $\mathrm{C}$ of $\mathrm{HBV}$ (C11).

\section{ACKNOWLEDGMENTS}

We are grateful to R.H. Hutabarat, Y.P. Dachlan and Nasronudin for their cooperation; S. Izumi, N.M. Mertaniasih, N.N.T. Puspaningsih, E.B. Aksono and T Kusbardiati for their invaluable support; K. Poedjiati for her technical assistance; and also deeply appreciate the blood donors at the Blood Transfusion Unit-Indonesia Red Cross, Jayapura, who gave their blood.

\section{REFERENCES}

Arauz-Ruiz P, Norder H, Visoná KA, Magnius LO. 1997. Molecular epidemiology of hepatitis B virus in Central America reflected in the genetic variability of the small S gene. J Infect Dis 176:851-858.

Arauz-Ruiz P, Norder H, Robertson BH, Magnius LO. 2002. Genotype $\mathrm{H}$ : A new Amerindian genotype of hepatitis B virus revealed in Central America. J Gen Virol 83:2059-2073.

Banerjee A, Kurbanov F, Sibnarayan D, Chandra PK, Tanaka Y, Mizokami M, Chakravarty R. 2006. Phylogenetic relatedness and genetic diversity of hepatitis B virus isolates in Eastern India. J Med Virol 78:1164-1174.

Bozdayi G, Turkyilmaz AR, Idilman R, Karataylii E, Rota S, Yurdaydin C, Bozdayi AM. 2005. Complete genome sequence and phylogenetic analysis of hepatitis B virus isolated from Turkish patients with chronic HBV infection. J Med Virol 76:476-481.

Chan HLY, Tsui SKW, Tse CH, Ng YET, An TCC, Yuen L, Bartholomeusz A, Leung KS, Lee KH, Locarnini S, Sung JJY. 2005. Epidemiological and virological characteristics of 2 subgroups of hepatitis B virus genotype C. J Infect Dis 191:2022-2033.

Djoht DR. 2002. The application of medical anthropology in health development of Papua societies. Anthropol Papua 1:9-19.

Feil D. 1995. The evolution of highland Papua New Guinea societies: A reappraisal. Bijdragen tot de Taal-, Land- en Volkenkunde 151:2343.

Hannoun C, Norder H, Lindh M. 2000. An aberrant genotype revealed in recombinant hepatitis B virus strains from Vietnam. J Gen Virol 81:2267-2272

Huy TTT, Ushijima H, Quang VX, Win KM, Luengrojanakul P, Kikuchi K, Sata T, Abe K. 2004. Genotype C of hepatitis B virus can be classified into at least two subtribes. J Gen Virol 85:283292

Kao JH. 2002. Hepatitis B viral genotypes: Clinical relevance and molecular characteristics. J Gastroenterol Hepatol 17:643-650.

Kao JH, Chen PJ, Lai MY, Chen DS. 2000. Clinical and virological aspects of blood donors infected with hepatitis $\mathrm{B}$ virus genotypes $\mathrm{B}$ and C. J Clin Microbiol 40:22-25.

Khan M, Dong JJ, Acharya SK, Dhagwahdorj Y, Abbas Z, Jafri W, Mulyono DH, Tozun N, Sarin SK. 2004. Hepatology issues in Asia: Perspective from regional leaders. J Gastroenterol Hepatol 19:419_ 430.

Kidd-Ljunggren K, Miyakawa, Y, Kidd AH. 2002. Genetic variability in hepatitis B viruses. J Gen Virol 83:1267-1280.

Kramvis A, Kew M, François G. 2005. Hepatitis B virus genotypes. Vaccine 23:2409-2423.

Lole KS, Bollinger RC, Paranjape RS, Gadkari D, Kulkarni SS, Novak NG, Ingersoll R, Sheppard HW, Ray SC. 1999. Full-length human immunodeficiency virus type 1 genomes from subtype C-infected seroconverters in India, with evidence of intersubtype recombination. J Virol 73:152-160.
Lusida MI, Nugrahaputra VE, Soetjipto, Handajani R, Nagano-Fujii M, Sasayama M, Utsumi T, Hotta H. 2008. Novel subgenotypes of hepatitis $\mathrm{B}$ virus genotypes $\mathrm{C}$ and $\mathrm{D}$ in Papua, Indonesia. $\mathrm{J}$ Clin Microbiol 46:2160-2166.

Magnius LO, Norder H. 1995. Subtypes, genotypes and molecular epidemiology of the hepatitis $B$ virus as reflected by sequence variability of the S-gene. Intervirology 38:24-34.

Mulyanto, Tsuda F, Karossi AT, Soewignjo S, Roestamsjah, Sumarsidi D, Trisnamurti RH, Sumardi M, Surayah, Udin LZ, MelaniWikanta, Kanai K, Mishiro S. 1997. Distribution of the hepatitis $\mathrm{B}$ surface antigen subtypes in Indonesia: Implications for ethnic heterogeneity and infection control measures. Arch Virol 142 2121-2129.

Mulyanto, Depamede SN, Surayah K, Tsuda F, Ichiyama K, Takahashi M, Okamoto H. 2009. A nationwide molecular epidemiological study on hepatitis B virus in Indonesia: Identification of two novel subgenotypes, B8 and C7. Arch Virol 154:1047-1059.

Mulyanto, Depamede SN, Surayah K, Tjahyono AAH, Jirintai, Nagashima S, Takahashi M, Okamoto H. 2010. Identification and characterization of novel hepatitis B virus subgenotype C10 in Nusa Tenggara, Indonesia. Arch Virol 155:705-715.

Nagasaki F, Niitsuma H, Cervantes JG, Chiba M, Hong S, Ojima T, Ueno Y, Bondoc E, Kobayashi K, Ishii M, Shimosegawa T. 2006. Analysis of the entire nucleotide sequence of hepatitis $\mathrm{B}$ virus genotype $B$ in the Philippines reveals a new subgenotypes of genotype B. J Gen Virol 87:1175-1180.

Norder H, Couroucé AM, Magnius LO. 1994. Complete genomes, phylogenetic relatedness, and structural proteins of six strains of the hepatitis B virus, four of which represent two new genotypes. Virology 198:489-503.

Norder H, Couroucé AM, Coursaget P, Echevarria JM, Lee S-D Mushahwar IK, Robertson BH, Locarnini S, Magnius LO. 2004. Genetic diversity of hepatitis B virus strains derived worldwide: Genotypes, subgenotypes, and $\mathrm{HBsAg}$ subtypes. Intervirology 47:289-309

Nuraeny N, Muljono DH, Sudoyo H, Marzuki S. 2008. Genetic study of hepatitis B virus in Indonesia reveals a new subgenotype of genotype B in east Nusa Tenggara. Arch Virol 153:10571065.

Okamoto H, Tsuda F, Sakugawa H, Sastrosoewignjo RI, Imai M, Miyakawa Y, Mayumi M. 1988. Typing hepatitis B virus by homology in nucleotide sequence: Comparison of surface antigen subtypes. J Gen Virol 69:2575-2583.

Olinger CM, Jutavijittum P, Hubschen JM, Yousukh A, Samontry B Thammavong T, Toriyama K, Muller CP. 2008. Possible new hepatitis B virus genotype, Southeast Asia. Emerg Infect Dis 14:1777-1780.

Orito E, Ichida T, Sakugawa H, Sata M, Horiike N, Hino K, Okita K Okanoue T, Iino S, Tanaka E, Suzuki K, Wanatabe H, Hige S, Mizokami M. 2001. Geographical distribution of hepatitis B virus (HBV) genotype in patients with chronic HBV infection in Japan. Hepatology 34:590-594.

Robertson DL, Hahn BH, Sharp PM. 1995. Recombination in AIDS viruses. J Mol Evol 40:249-259.

Sakamoto T, Tanaka Y, Orito E, Co J, Clavio J, Sugauchi F, Ito K, Ozasa A, Quino A, Ueda R, Sollano J, Mizokami M. 2006. Novel subtypes (subgenotypes) of hepatitis $\mathrm{B}$ virus genotypes $\mathrm{B}$ and $\mathrm{C}$ among chronic liver disease patients in the Philippines. J Gen Virol 87:1873-1882.

Sakamoto T, Tanaka Y, Simmonetti J, Osiowy C, Berresen M, Koch A Kurbanov F, Sugiyama M, Minuk G, McMahon J, Joh T, Mizokam M. 2007. Classification of hepatitis $B$ virus genotype $B$ into 2 major types based on characterization of a novel subgenotype in Arctic Indigenous population. J Infect Dis 196:1487-1492.

Sastrosoewignjo RI, Sandjaja B, Okamoto H. 1991. Molecular epidemiology of hepatitis B virus in Indonesia. J Gastroenterol Hepatol 6:491-498.

Schaefer S. 2007. Hepatitis B virus taxonomy and hepatitis B virus genotypes. World J Gastroenterol 13:14-21.

Sofro ASM. 1982. Population genetic studies in Indonesia. Dissertation. Canberra: Australian National University.

Stuyver L, De Gendt S, Van Geyt C, Zoulim F, Fried M, Schinazi RF, Rossau R. 2000. A new genotype of hepatitis B virus: Complete genome and phylogenetic relatedness. J Gen Virol 81:67-74.

Sugauchi F, Mizokami M, Orito E, Ohno T, Kato H, Suzuki S, Kimura Y, Ueda R, Butterworth LA, Cooksley WGE. 2001. A novel variant genotype $\mathrm{C}$ of hepatitis $\mathrm{B}$ virus identified in isolates from Australian 
Aborigines: Complete genome and phylogenetic relatedness. J Gen Virol 82:883-892.

Tatematsu K, Tanaka Y, Kurbanov F, Sugauchi F, Mano S Maeshiro T, Nakayoshi T, Wakuta M, Miyakawa Y, Mizokami M. 2009. A genetic variant of hepatitis B virus divergent from known human and ape genotypes isolated from a Japanese patient and provisionally assigned to new genotype J. J Virol 83:1053810547.
Usuda S, Okamoto H, Iwanari H, Baba K, Tsuda F, Miyakawa Y, Mayumi M. 1999. Serological detection of hepatitis B virus genotypes by ELISA with monoclonal antibodies to type-specific epitopes in the preS2-region product. J Virol Methods 80:97-112.

Utsumi T, Lusida MI, Yano Y, Nugrahaputra VE, Amin M, Juniastuti, Hayashi Y, Hotta H. 2009. Complete genome sequences and phylogenetic relatedness of hepatitis B virus isolates in Papua, Indonesia. J Clin Microbiol 47:1842-1847. 